\title{
Aluminium-Containing Municipal-Waste Ash and the Greenhouse Effect
}

\author{
Petr Buryan, Tomáš Hlinčík* \\ Department of Gaseous and Solid Fuels and Air Protection, University of Chemistry and Technology, \\ Prague, Czech Republic
}

Received: 19 October 2018

Accepted: 26 March 2019

\begin{abstract}
Laboratory findings on the reactions of ash from solid municipal waste from aluminium-containing packages of typical food products indicate that the thermodynamic conditions in landfills and the metabolism of various bacterial strains lead to the formation of biomethane. In addition, laboratory measurements have shown that one kilogram of the waste ashes monitored generates 1821 of methane on average, which considering its relative radiation power corresponds to $9.0 \mathrm{~kg}$ of burnt brown coal. This implies the substantial influence of the resulting biomethane on the greenhouse effect when these waste ashes are landfilled.
\end{abstract}

Keywords: aluminium, municipal waste, greenhouse effect, biomethane, packing

\section{Introduction}

The current status of waste utilization worldwide, while respecting its composition, also includes depositing it on landfills. Two types of waste are deposited in landfills: biodegradable and nonbiodegradable. Biodegradable materials can be decomposed by microorganisms under anaerobic or aerobic conditions. They include food-production waste, leftovers from meat and fish processing, waste from kitchens and restaurants, from the sale of food, garden waste, paper packaging, cotton materials, municipal waste, etc.

For assessing the possible amount of landfill and reactor biogas generated from biodegradable waste, an entire range of models derived from both theoretical

*e-mail: Tomas.Hlincik@vscht.cz and practical knowledge are applied [1]. The formation of biogas from the inorganic part of municipal and industrial waste or their ashes is not mentioned in the available literature.

Municipal waste is significantly dominated by aluminium-containing materials. Because of the character and weight of these small objects, it is not economically advantageous to sort and recycle them now. Therefore, these waste components are landfilled. Their incineration in the form of solid alternative fuels in conventional furnaces or power plants, where the temperature does not exceed $1,000^{\circ} \mathrm{C}$, does not solve this problem, because aluminium is not oxidised there. In addition, when the solid energy by-products formed here come in touch with water, their basicity causes the separation of hydrogen.

From the presented results it is obvious that the solid by-products generated by the combustion of wastes containing aluminum cannot be stored in exhausted coal mines. 


\section{Municipal Solid Waste Storage and Methane Formation}

A non-negligible part of solid municipal waste is currently stored at landfills, with only a part being incinerated to utilise its energy content. Waste disposal by either incineration or co-combustion with coal or biomass in boilers yields solid energy by-products. The thermodynamic conditions in these furnaces, however, are not sufficient for the complete oxidation of aluminium from the aluminium composites from waste package products to aluminium (III) oxide. Aluminium passes here into solid by-products in the form of metallic aluminium.

This is confirmed by the thermogravimetric curves obtained by heating different model packaging materials up to $1,000^{\circ} \mathrm{C}$ [2]. At these temperatures, aluminium does not yet oxidise to aluminium (III) oxide.

Along with the aforementioned substances, byproducts formed during the combustion of coal or alternative fuels or during the co-combustion of coal and biomass are deposited in the landfills. These are fly ashes, trapped in filters or devices reducing the emissions of particulate matter from combustion products or bottom ash and slag.

These substances, which are now mostly deposited in landfills, are mainly monitored with respect to their chemical composition and leachate properties. Because of their composition, the leachates have $\mathrm{pH} \geq 9$ (at $\mathrm{pH}$
6.0-6.5, acetotrophic methanogenesis takes place to produce methane and carbon dioxide) [3]. Aluminium content is not monitored.

The issue discussed is illustrated on the data provided in Table 1, acquired through x-ray fluorescence (XRF spectrometer ARL $9400 \mathrm{XP}$ ) analysis for energy by-products of the combustion of brown coal, biomass and solid alternative fuel on the basis of municipal waste $[4,5]$.

It is evident from Table 1 that the total content of alkaline (sodium, potassium and calcium) oxides is considerably higher in biomass ash than in coal ash. Therefore, also their leachates are more alkaline, especially when the ashes contain, besides oxides, also free lime $(\mathrm{CaO})$ and a number of encapsulating oxides, undergoing volume-expansion reactions diffusion of water into these ash particles [5]. The same applies to the ash from the combustion of solid alternative fuels.

The stability of aluminum in the co-incineration of different types of waste in fluidized bed boilers is evident from x-ray diffractometry analysis (XRD - diffractometer Pananalytical X Pert Pro) of the by-products shown in Table 2. Aluminum does not significantly participate in the reactions of inorganic materials in the generation of solid by-products.

The hydration of alkaline oxides in landfills leads to the formation of hydroxides, which subsequently react with aluminium to form hydrogen and soluble hydroxo complexes, e.g. according to the Equations [6]:

Table 1. Brown coal, biomass and alternative solid fuel ash composition - wt. \%.

\begin{tabular}{|c|c|c|c|c|}
\hline Sample & $\begin{array}{l}\text { Brown coal } \\
\text { (Lignite) }\end{array}$ & $\begin{array}{l}\text { Biomass pellets } \\
\text { (Hay, wheat) }\end{array}$ & $\begin{array}{l}\text { Wood pellets } \\
\text { (Spruce) }\end{array}$ & $\begin{array}{l}\text { Solid alternative fuel } \\
\text { (Municipal waste) }\end{array}$ \\
\hline $\mathrm{Na}_{2} \mathrm{O}$ & 0.94 & 0.15 & 0.92 & 6.71 \\
\hline $\mathrm{MgO}$ & 0.87 & 13.33 & 5.87 & 1.82 \\
\hline $\mathrm{Al}_{2} \mathrm{O}_{3}$ & 31.50 & 0.08 & 0.96 & 18.67 \\
\hline $\mathrm{SiO}_{2}$ & 53.60 & 1.61 & 2.40 & 20.75 \\
\hline $\mathrm{P}_{2} \mathrm{O}_{5}$ & 0.21 & 48.67 & 2.64 & 0.69 \\
\hline $\mathrm{SO}_{3}$ & 0.63 & 0.11 & 1.28 & 2.02 \\
\hline $\mathrm{K}_{2} \mathrm{O}$ & 1.32 & 31.57 & 12.08 & 1.25 \\
\hline $\mathrm{CaO}$ & 1.79 & 3.44 & 71.09 & 39.14 \\
\hline $\mathrm{TiO}_{2}$ & 2.41 & - & 0.07 & 3.03 \\
\hline $\mathrm{Cr}_{2} \mathrm{O}_{3}$ & 0.05 & - & - & 0.05 \\
\hline $\mathrm{MnO}$ & 0.03 & 0.36 & 1.35 & 0.09 \\
\hline $\mathrm{Fe}_{2} \mathrm{O}_{3}$ & 6.32 & 0.35 & 0.43 & 1.84 \\
\hline $\mathrm{CuO}$ & 0.01 & 0.03 & 0.03 & 0.04 \\
\hline $\mathrm{ZnO}$ & 0.01 & 0.24 & 0.36 & 0.22 \\
\hline $\mathrm{SrO}$ & 0.02 & 0.02 & 0.28 & 0.05 \\
\hline $\mathrm{BaO}$ & 0.06 & - & - & 0.11 \\
\hline $\mathrm{Cl}$ & - & - & - & 3.30 \\
\hline
\end{tabular}


Table 2. XRD analysis of the-by products of co-incineration.

\begin{tabular}{|c|c|c|c|}
\hline Compound name & Mineral name & Chem. Formula & $\begin{array}{c}\text { Quantity } \\
{[\text { wt. \% ] }}\end{array}$ \\
\hline Silicon Oxide & Quartz, syn & $\mathrm{SiO}_{2}$ & 42 \\
\hline Iron Oxide & Hematite, syn & $\mathrm{Fe}_{2} \mathrm{O}_{3}$ & 18 \\
\hline Calcium Sulfate & & $\mathrm{CaSO}_{4}$ & 17 \\
\hline Potassium Sodium Aluminum Silicate & Sanidine & $\mathrm{K}_{0.831} \mathrm{Na}_{0.169} \mathrm{AlSi}_{3} \mathrm{O}_{8}$ & 8 \\
\hline Potassium Aluminum Iron Silicate Hydroxide & Muscovite-2M1, ferroan & $\mathrm{K}(\mathrm{Al}, \mathrm{Fe})_{2} \mathrm{AlSi}_{3} \mathrm{O}_{10}(\mathrm{OH})_{2}$ & 11 \\
\hline Titanium Oxide & Rutile, syn & $\mathrm{TiO}_{2}$ & 4 \\
\hline
\end{tabular}

$$
\begin{array}{r}
2 \mathrm{Al}+2 \mathrm{KOH}+6 \mathrm{H}_{2} \mathrm{O} \rightarrow 3 \mathrm{H}_{2}+2 \mathrm{~K}\left[\mathrm{Al}(\mathrm{OH})_{4}\right] \\
2 \mathrm{Al}+2 \mathrm{NaOH}+6 \mathrm{H}_{2} \mathrm{O} \rightarrow 3 \mathrm{H}_{2}+2 \mathrm{Na}\left[\mathrm{Al}(\mathrm{OH})_{4}\right]
\end{array}
$$

The hydroxo complexes further decompose into hydroxides [6]:

$$
\begin{aligned}
\mathrm{K}\left[\mathrm{Al}(\mathrm{OH})_{4}\right] & \rightarrow \mathrm{KOH}+\mathrm{Al}(\mathrm{OH})_{3} \\
\mathrm{Na}\left[\mathrm{Al}(\mathrm{OH})_{4}\right] & \rightarrow \mathrm{NaOH}+\mathrm{Al}(\mathrm{OH})_{3}
\end{aligned}
$$

...which can react again according to Equations (1) and (2).

The release of free $\mathrm{CaO}$ from the secondary energy products of desulphurization of the flue gas by the dry method and its activity in the formation of hydrogen in landfills is described in the following equations.

In the first stage, calcium sulfate forms a dihydrate. It dissolves, thereby releasing free $\mathrm{CaO}$. The free $\mathrm{CaO}$ reacts further with water to form a hydroxide, which reacts with aluminum with reactions (5) and (6) [6]:

$2 \mathrm{Al}+3 \mathrm{Ca}(\mathrm{OH})_{2}+6 \mathrm{H}_{2} \mathrm{O} \rightarrow 3 \mathrm{H}_{2}+3 \mathrm{CaO} \cdot \mathrm{Al}_{2} \mathrm{O}_{3} \cdot 6 \mathrm{H}_{2} \mathrm{O}$

$$
2 \mathrm{Al}+\mathrm{Ca}(\mathrm{OH})_{2}+6 \mathrm{H}_{2} \mathrm{O} \rightarrow 3 \mathrm{H}_{2}+\mathrm{Ca}\left[\mathrm{Al}(\mathrm{OH})_{4}\right]_{2}
$$

Reactions (5) and (6) precede the long-time dissolution of $\mathrm{CaSO}_{4}$, and therefore the release of hydrogen is relatively long in this case.

The hydrogen generated in reactions (1) and (2) can then be involved in the extensive landfill biosynthesis process schematically depicted in Fig. 1, an inseparable product of which is biomethane according to Equation [7]:

$$
4 \mathrm{H}_{2}+\mathrm{CO}_{2} \rightarrow \mathrm{CH}_{4}+2 \mathrm{H}_{2} \mathrm{O}
$$

The rates of all the reactions above increase with temperature, which is also the case in landfills, where the temperature often exceeds $50^{\circ} \mathrm{C}$. The optimal temperature for hydrogenotrophic methanogens is $60^{\circ} \mathrm{C}$ [8].

The metabolism of methanogenic populations depends on a series of factors such as the amount of oxygen in the environment, temperature, humidity, the sources and structure of organic carbonaceous substances, the sources of energy, symbiosis with other (in particular acidogenic) bacteria, $\mathrm{pH}$, the presence of

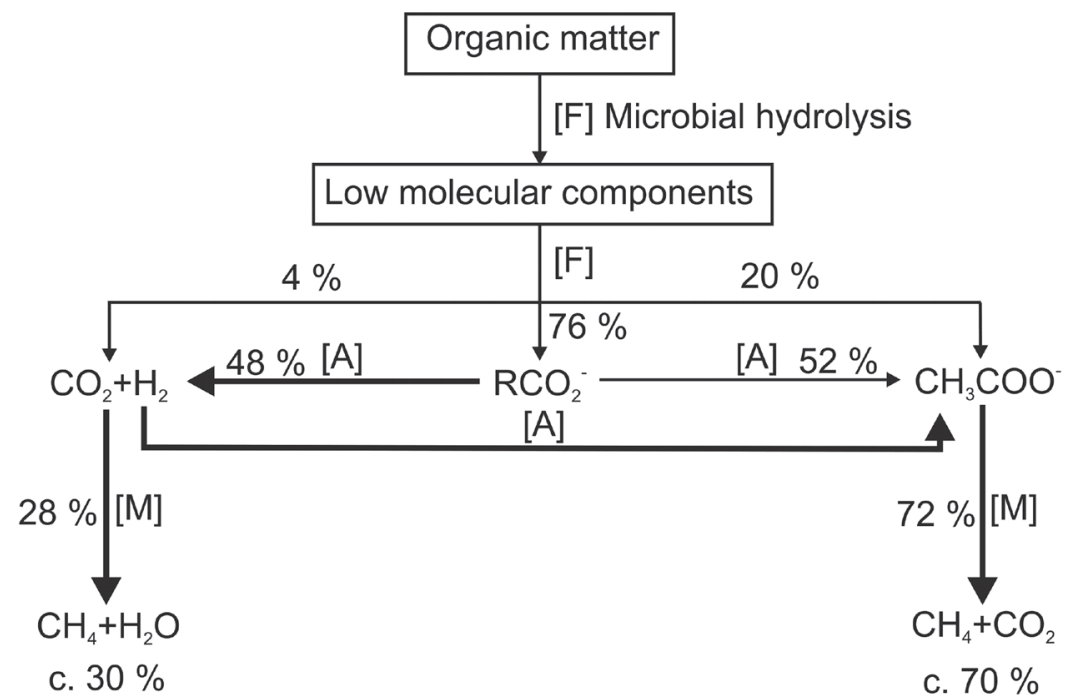

Fig. 1. A simplified scheme of bacterial biogas formation [6] (F - fermentation, $\mathrm{A}$ - acetogenesis, $\mathrm{M}$ - methanogenesis). 
toxic compounds, $\mathrm{NH}_{3}$ quantity, etc. [9-13]. According to Bryant [14], these processes involve mainly three genera of methanogens: methanobacterium, methanosarcina and methanococcus.

Unless the landfill gas containing methane is collected, it is emitted into the atmosphere. For the sake of simplification, the methanotrophic and oxidation processes that take place in the upper part of a landfill site, i.e., in the landfill cover soil, will be neglected below.

Methane is a major atmospheric pollutant with a more potent greenhouse effect than carbon dioxide. The relative radiative effect of methane is 34 times stronger than that of carbon dioxide [15].

It can thus be stated based on Equation (7) that, instead of $\mathrm{CO}_{2}$, mostly formed through bio substance degradation, the process leads to the release of methane, whose greenhouse effect is much stronger.

\section{Experimental}

\section{Sample Characterization}

From the aluminium-containing municipal waste monitored (whose ashes were analysed by x-ray fluorescence), 10 typical food-packaging categories were chosen, including cheese, coffee, candy, medicine, butter, wafer, spray, yogurt and heavy cream packaging, and wine and liquor caps. Each of the categories contained at least four different packaging types of the given product. These samples were subsequently incinerated in a muffle furnace at a temperature of $1,000^{\circ} \mathrm{C}$ in order to simulate waste combustion in municipal waste incineration plants. In order to clarify and increase the impact of the experimental results acquired, the average values of each category are discussed below. Using x-ray diffractometry and spectrometry, it was found that the analysed ashes contained aluminum; other metals were not identified.

\section{Analytical Method}

The captured gas from the laboratory measurement was pumped to the HP 7890A gas chromatograph dispensing loop with a volume of $0.25 \mathrm{~cm}^{3}$. This gas chromatograph contained two detectors: plate ionization (FID) and thermal conductivity (TCD). A total of four chromatographic columns were used for analysis. The pre-column consisted of an HP Haysep Q 80/100 mesh packing column. The capillary column RT-Alumina $0.53 \mathrm{~mm}$ in diameter and $50 \mathrm{~m}$ in length was used to separate the hydrocarbons. HP Pora Plot Q capillary columns $0.53 \mathrm{~mm}$ in diameter and $30 \mathrm{~m}$ length were used to separate the permanent gases, HP Mol Sieves $5 \mathrm{~A}$ Capillary Column with a diameter of $0.53 \mathrm{~mm}$ and a length of $30 \mathrm{~m}$. Detectors were heated to $250^{\circ} \mathrm{C}$ (FID) and $210^{\circ} \mathrm{C}$ (TCD). The measured results were evaluated by the integration method.

\section{Methane Formation Modelling}

For the illustration and more detailed explanation of the reactions of ash from aluminium-containing solid municipal waste in landfills, a model study was conducted based on 10 categories of selected packaging made of aluminium composite materials that are commonly disposed of in municipal waste containers (see Table 3).

The packaged ash samples were weighed and inserted into the model apparatus shown in Fig. 2. They were decomposed using a solution containing potassium hydroxide in the molar concentration of $0.1 \mathrm{~mol} / \mathrm{l}$. The formed gas - hydrogen (analysed via gas chromatography coupled with mass spectrometry detection) - was collected in calibrated containers of different sizes, depending on the weight of the waste inserted. All the tested samples underwent fully the reaction within 24 hours.

In order to determine the influence of temperature on the generation of hydrogen from landfill waste, the individual types of waste from which hydrogen was produced slowly at room temperature were subjected to the same process at $60^{\circ} \mathrm{C}$, which is the temperature measured at landfill sites [16]. In all the cases studied, the formation of hydrogen was substantial and even several times higher than at room temperature.

The experimental results are given in the following tables, including the recorded volume of the hydrogen produced, and the calculated volume of the methane that would be formed from the particular volume of hydrogen due to bacterial activity in a landfill site (see Table 3). The model calculation assumed 100\% conversion of hydrogen to methane. Table 4 contains these data calculated for $1 \mathrm{~kg}$ of the same waste. So that it would be possible to compare the influence

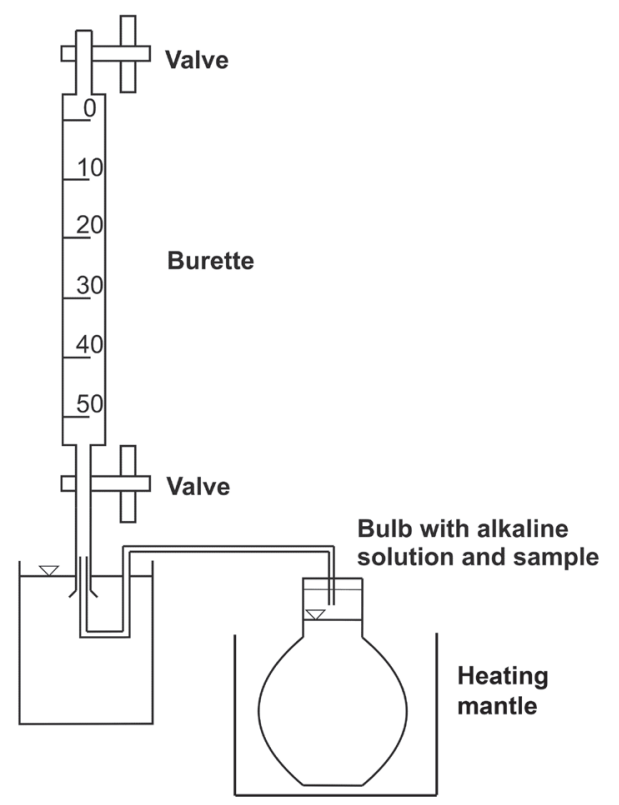

Fig. 2. Laboratory experimental apparatus. 
Table 3. Volume of the hydrogen and methane formed from aluminium-containing waste.

\begin{tabular}{|c|c|c|c|}
\hline Package type & Average weight $[\mathrm{g}]$ & $\begin{array}{c}\text { Average hydrogen volume } \\
{\left[\mathrm{dm}^{3}\right]^{*}}\end{array}$ & $\begin{array}{c}\text { Average methane volume } \\
{\left[\mathrm{dm}^{3}\right]^{*}}\end{array}$ \\
\hline Butter package & 4.34 & 1.17 & 0.30 \\
\hline Coffee package & 0.56 & 0.42 & 0.11 \\
\hline Cheese package & 2.53 & 1.18 & 0.30 \\
\hline Medicine package & 5.11 & 1.81 & 0.46 \\
\hline Candy package & 1.47 & 1.28 & 0.13 \\
\hline Yogurt and heavy cream package & 0.43 & 0.53 & 6.00 \\
\hline Spray package & 21.10 & 24.00 & 0.36 \\
\hline Wafer package & 4.40 & 1.44 & 0.31 \\
\hline Wine caps & 1.82 & 1.24 & 0.74 \\
\hline Liquor caps & 2.87 & 3.25 & 0 \\
\hline
\end{tabular}

* Laboratory conditions

of anthropogenic emissions of methane with carbon dioxide released during brown-coal combustion, Table 4 also shows the equivalent amount based on the weight of the incinerated wet brown coal (22 wt. \% of water, 25 wt. $\%$ of ash, 50 wt. $\%$ of carbon in the combustible) in a local furnace.

\section{Results and Discussion}

Hydrogen formation resulting from the reaction of the ash from aluminium-containing municipal waste stored in landfill sites with alkaline leachates has been experimentally confirmed. The hydrogen generated from the food packages monitored (see Table 3), which form a common part of solid communal waste, is thus an important methane precursor. Among the food packages compared, the highest amount of hydrogen was generated by the spray category, followed by the liquor caps. The smallest amount of hydrogen in landfills was generated by coffee packages.

\section{Conclusions}

The theoretical and experimental knowledge acquired indicates that one of the abiogenic/biogenic processes taking place in landfill sites with ashes from aluminium-containing waste is the formation of methane, which is the basic component of landfill biogas. During these processes, aluminium functions as a source of hydrogen, which is subsequently

Table 4. Volume of the methane formed per $1 \mathrm{~kg}$ of waste.

\begin{tabular}{|c|c|c|c|}
\hline Package type & Average methane volume $\left[\mathrm{dm}^{3}{ }^{*}\right.$ & $\mathrm{CO}_{2}$ volume $\left[\mathrm{dm}^{3}\right]^{*}$ & Brown coal $[\mathrm{kg}]$ \\
\hline Butter package & 67.75 & 2304.40 & 3.35 \\
\hline Coffee package & 196.40 & 6678.38 & 9.68 \\
\hline Cheese package & 121.30 & 4125.54 & 5.97 \\
\hline Medicine package & 119.50 & 4062.64 & 10.01 \\
\hline Candy package & 203.27 & 6901.15 & 14.89 \\
\hline Yogurt and heavy cream package & 302.25 & 10207.80 & 14.00 \\
\hline Spray package & 284.40 & 9668.02 & 4.03 \\
\hline Wafer package & 81.80 & 2781.77 & 9.45 \\
\hline Wine caps & 191.75 & 6518.79 & 12.47 \\
\hline Liquor caps & 253.17 & 6185.46 & 8.98 \\
\hline Average & 182.16 & & \\
\hline
\end{tabular}

* Laboratory conditions 
transformed into methane through the effect of methanogenic bacteria from the bacterial activities of the formed carbon dioxide. In landfill sites without sufficient gas extraction, the methane is freely released into the atmosphere. Based on the relationship between the radiation effect of methane and the relative radiation effect of carbon dioxide, it is possible to determine the influence of the landfilling of aluminium-containing waste on the greenhouse effect.

The average amount of carbon dioxide formed from $1 \mathrm{~kg}$ of the monitored waste incineration ash was ca 6,185 1, i.e., 141 g. One average kilogram of the types of waste studied thus corresponds its carbon dioxide emission to $9 \mathrm{~kg}$ of typical wet brown coal combusted in a local furnace.

The current knowledge of methane formation in landfill sites can hence be augmented by a new abiogenic source, namely aluminium-containing inorganic materials.

The relative absorption effect of the greenhouse gases produced by human activity can thus be complemented by methane formed from the ashes of common aluminium-containing food packages deposited in landfill sites.

The results of the experiments show that in order to reduce the negative impacts of the monitored waste it is necessary to ensure the separation of the aluminum materials and the removal of the waste gases and subsequently to utilize their energy content.

\section{Conflict of Interest}

The authors declare no conflict of interest.

\section{References}

1. REES J.F. The fate of carbon compounds in the landfill disposal of organic matter. J. Chem. Technol. Biotechnol. 30, 161, 1980.

2. BURYAN P., HORAK J., JANKOVSKA Z., HOPAN F., KRPEC K., KUBESA P. Evolution of flammable gases from dumping municipal waste. Chem. Listy. 107, 355, 2013.
3. PENG W., PIVATO P.A., LAVAGNOLO M.C., RAGA R. Digestate application in landfill bioreactors to remove nitrogen of old landfill leachate. Waste Management. 74, $335,2018$.

4. BURYAN P., VEJVODA J., KRATKY J., VEVERKA L. The causation of high limestone consumption in coal desulfurization fluidized bed boiler. Ceramics - Silikaty. 54, 85, 2010.

5. BURYAN P. The influence of alternative solid fuels on desulfurization of fluidized bed boilers. Chem. Listy. 109, 635, 2015.

6. BURYAN P., HLINCIK T. A new theory of the creation of biomethane from aluminium-containing inorganic wastes. J. Mater. Cycles Waste Manag. 18, 258, 2016.

7. HUNT J.M. Petroleum Geochemistry and Geology, 2nd ed. San Francisco, W. H. Freeman, 2015.

8. UEMURA S., HARADA H. Microbial characteristics of methanogenic sludge consortia developed in thermophilic UASB reactors. Appl. Microbiol. Biotechnol. 39, 654, 1993.

9. CAN L., HUAN L., YUYAO Z., QINGWU C. Characterization of methanogenic activity during highsolids anaerobic digestion of sewage sludge. Biochemical Engineering Journal. 109, 96, 2016.

10. DU J., HU Y., QI W., ZHANG Y., JING Z., NORTON M., LOI Y.Y. Influence of four antimicrobials on methaneproducing archaea and sulfate-reducing bacteria in anaerobic granular sludge. Chemosphere. 140, 184, 2015.

11. ZAHEDI S. Changes in microbial community during hydrogen and methane production in two-stage thermophilic anaerobic co-digestion process from biowaste. Waste Management. 49, 40, 2016.

12. RUI S. Methane production and microbial community structure for alkaline pretreated waste activated sludge. Bioresour. Technol. 169, 496, 2014.

13. MALI S., KHARE K.C., BIRADAR A.H. Enhancement of methane production and bio-stabilisation of municipal solid waste in anaerobic bioreactor landfill. Bioresour. Technol. 110, 10, 2012.

14. BRYANT M.P. Methane-producing bacteria. Bergey's Manual of Determinative Bacteriology, 8th ed. Baltimore, The Williams \& Wilkins Co, 1974.

15. MULLER R.A., MULLER E.A. Fugitive methane and the role of atmospheric half-life. Geoinformatics \& Geostatistics: An Overview. 5, 1, 2017.

16. BOUAZZA A., NAHLAWI H., AYLWARD M. In situ temperature monitoring in an organic-waste landfill cell. Journal of Geotechnical and Geoenvironmental Engineering. 137, 1286, 2011. 